\title{
Conformational and Ion Binding Properties of a Cyclic Octapeptide, cyclo(Ala-Leu-Pro-Gly) ${ }_{2}$
}

\author{
D. S. SEETHARAMA JOIS, ${ }^{2}$ K. R. K. EASWARAN, ' MARIA BEDNAREK, ${ }^{2 \star \star}$ and E. R. BLOUT ${ }^{2}$ \\ ${ }^{1}$ Molecular Biophysics Unit, Indian Institute of Science, Bangalore, India; and ${ }^{2}$ Department of Biological Chemistry \\ and Molecular Pharmacology, Harvard Medical School, Boston, Massachussetts 02115, USA
}

\begin{abstract}
SYNOPSIS
The conformation and ion-binding characteristics of a cyclic octapeptide, cyclo (Ala-LeuPro-Gly $)_{2}$, in a liphophilic solvent, acetonitrile, have been studied using CD and $\mathrm{nmr}$ spectroscopy. The peptide binds preferentially to divalent cations such as calcium, magnesium, and barium. The conformations of the free cyclic peptide and its calcium complex are very similar with well-defined $\beta$ - and $\gamma$-turns. The cyclic peptide readily forms equimolar and possibly $2: 1$ (peptide:cation) complexes with divalent cations.
\end{abstract}

\section{INTRODUCTION}

Studies on various synthetic and naturally occurring cyclic peptides and peptide antibiotics that are capable of binding cation have been extremely useful in the understanding of the molecular mechanism of carrier-mediated transmembrane ion transport. ${ }^{1-5}$ Synthetic cyclic peptides ${ }^{6-8}$ and bicyclic peptides ${ }^{9-13}$ with well-defined backbone conformation are particularly interesting as models for understanding the biologically active conformation and ion-binding properties of naturally occurring peptides and peptide antibiotics. Understanding the various conformational possibilities of the peptides with varying side chains, and the sequence and the number of amino acid residues in the cyclic peptide and the binding properties of the peptides with cations of different sizes, is very important in developing structure-function relationships.

In this paper, we report our detailed studies on the conformational and ion-binding aspects of a synthetic cyclic octapeptide, cyclo(Ala-Leu-ProGly $)_{2}$, in acetonitrile as a part of our detailed studies on a series of cyclic and bicyclic peptides as possible ionophores, using $\mathrm{CD}$ and $\mathrm{nmr}$ methods. Our results indicate that this cyclic peptide has well-defined

Biopolymers, Vol. 32, 993-1001 (1992)

(C) 1992 John Wiley \& Sons, Inc.

CCC 0006-3525/92/080993-09\$04.00

* Present address: Merck Sharp and Dohme, Rahway, New Jersey 07065 . conformations having $\beta$ - and $\gamma$-turns, and selectively binds to calcium ion forming a $2: 1$ sandwich (peptide : calcium) and 1:1 (equimolar) complex.

\section{MATERIALS AND METHODS}

\section{Synthesis of Peptide}

Tetrahydrofuran (THF) and dimethylformamide (DMF) were dried over molecular sieves, Davison grade 514, type 4A. Thin layer chromatography was performed on precoated silica gel plates in the following solvent systems: (A) chloroform-methanol (9:1), (B) chloroform-methanol (19:1), (C) ethyl acetate-pyridine-acetic acid-water $(65: 20: 6: 12)$, and (D) chloroform-methanol-acetic acid (9:1 ; 0.1 ). Plates were visualized under a uv lamp, with iodine vapors, ninhydrin solution, or by charring.

Boc-Pro-Gly-OBzl (I). This was prepared as described by Deber and Blout. ${ }^{18}$

Boc-Leu-Pro-Gly-OBzI (II). A sample of Boc-Leu$\mathrm{OH} \mathrm{H}_{2} \mathrm{O}(3.7 \mathrm{~g}, 15 \mathrm{mmol})$ was dissolved in DCM, cooled to $-15^{\circ} \mathrm{C}$ in an acetone-dry ice bath, and treated with $\mathrm{N}$-methylmorpholine (NMM; $1.7 \mathrm{~mL}$, $15 \mathrm{mmol}$ ) and iso-butylchlorocarbonate (iBCC; 2 $\mathrm{mL}, 15 \mathrm{mmol}$ ). After $10 \mathrm{~min}$, a solution of the TFAdeprotected and NMM-neutralized dipeptide (I) in DCM was added $(5.4 \mathrm{~g}, 15 \mathrm{mmol})$. The reaction 


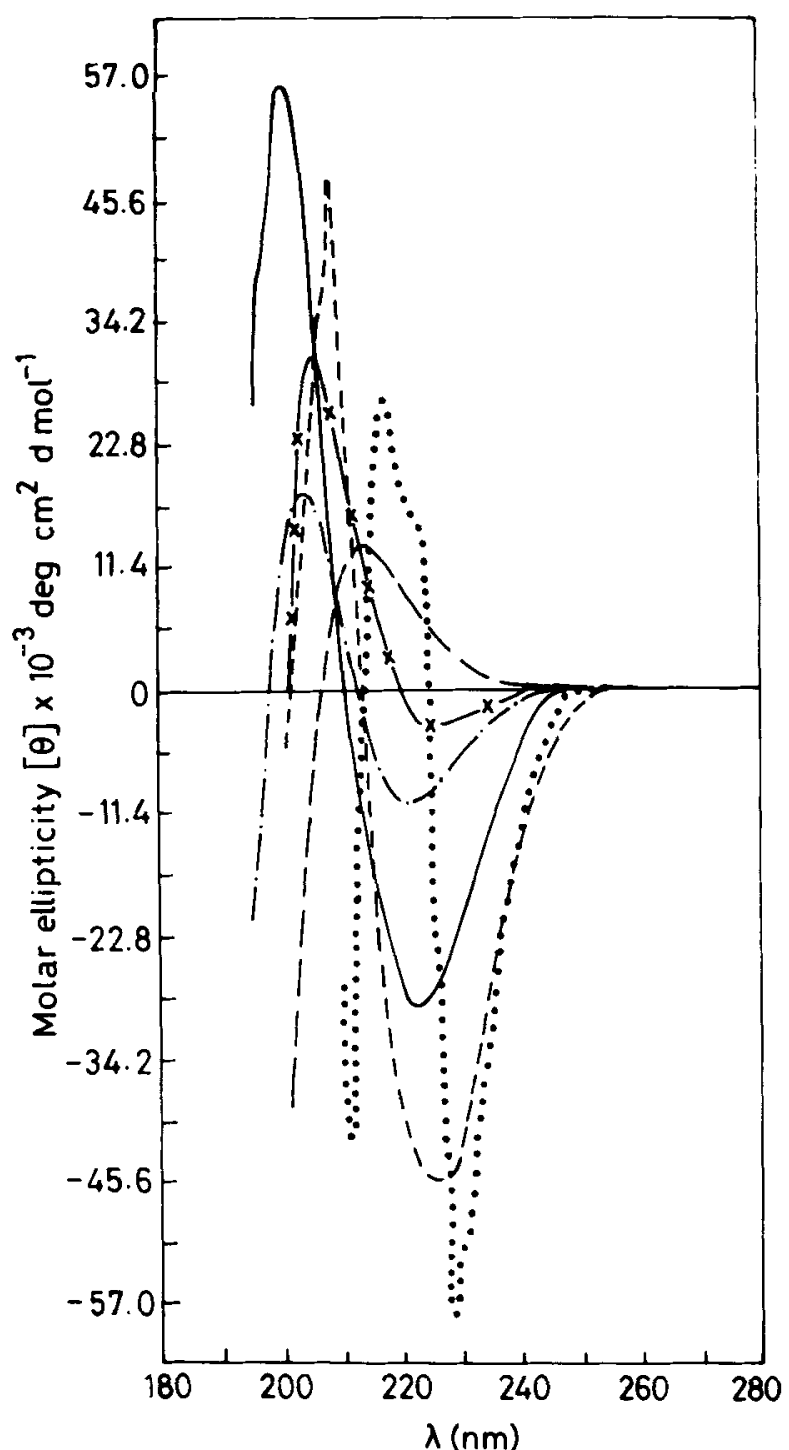

Figure 1. CD spectra of free cyclo (Ala-Leu-Pro-Gly $)_{2}$ in various solvents. (-) Acetonitrile, $(-\cdot)$ methanol, $(--)$ water, $(-\mathbf{x})$ trifluroethanol, ( ...) chloroform, (-. ) hexane. Concentration of the peptide was 3.94 $\times 10^{-4}$ molar.

mixture was stirred at $-15^{\circ} \mathrm{C}$ for $0.5 \mathrm{~h}$ and then allowed to warm up to room temperature. Subsequently, it was washed with $5 \%$ citric acid, water, $0.5 \mathrm{~N} \mathrm{NaHCO}_{3}$, and water, and the organic phase was dried over $\mathrm{MgSO}_{4}$. Removal of $\mathrm{MgSO}_{4}$ by filtration and evaporation of DCM left an oily material with $92 \%$ yield $(6.6 \mathrm{~g}), R_{\mathrm{f}} \mathrm{A} 0.89, R_{\mathrm{f}} \mathrm{B} 0.47$.

Boc-Ala-Leu-Pro-Gly-OBzI (III). A protected peptide (II) ( $6.0 \mathrm{~g} 12.6 \mathrm{mmol}$ ) was dissolved in trifluoroacetic acid (TFA). After $15 \mathrm{~min}$ at room temperature, the solvent was removed in vacuo, and the residue was washed with ether and dried in vacuo over $\mathrm{NaOH}$ pellets.

A sample of Boc-Ala-OH (2.5 g, $13.0 \mathrm{mmol})$ in DCM was cooled to $-15^{\circ} \mathrm{C}$ and treated with NMM $(2.44 \mathrm{~mL}, 13.0 \mathrm{mmol})$ and $\mathrm{iBCC}(1.7 \mathrm{~mL}, 12.5$ mmol). After $10 \mathrm{~min}$ at $-15^{\circ} \mathrm{C}$, a solution of deblocked tripeptide (II) was added, and the reaction mixture was stirred overnight at room temperature. The workup, as described for compound (II), gave a chromatographically pure [thin layer chromatography (tlc)] form with $98 \%$ yield $(6.7 \mathrm{~g}) ; R_{\mathrm{f}} \mathrm{A} 0.67$.

Boc-Ala-Leu-Pro-Gly-OBzI (IV). Part of a protected peptide (III) ( $3.0 \mathrm{~g}, 5.5 \mathrm{mmol}$ ) was dissolved in $95 \%$ ethanol and hydrogenated at room temperature in the presence of $10 \%$ palladium on charcoal as a catalyst $(0.6 \mathrm{~g})$. After $3 \mathrm{~h}$ the catalyst was removed by filtration, the solvent evaporated, and the residue triturated with ether. The precipitate was filtered,

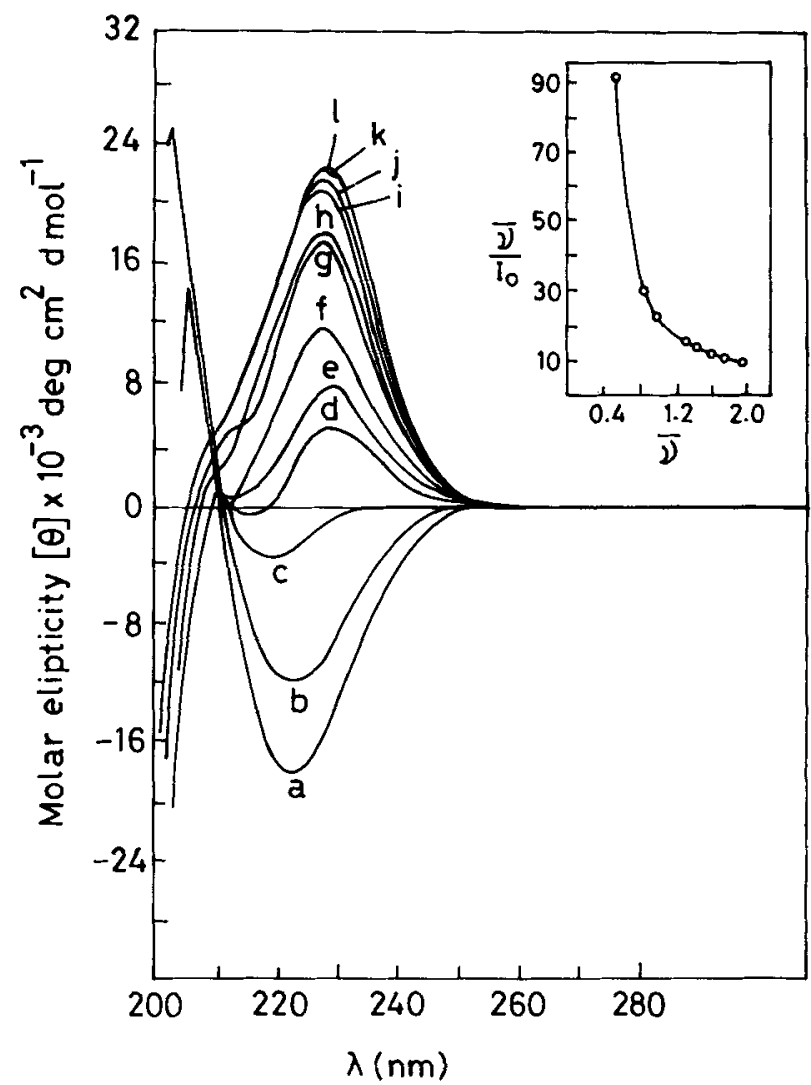

Figure 2. CD spectra of free cyclo (Ala-Leu-Pro-Gly) and its calcium complex in acetonitrile at the following molar concentration ratios of peptide : calcium perchlorate: (a) free peptide, (b) $1: 0.1$, (c) $1: 0.2$, (d) $1: 0.3$, (e) 1 : 0.4 , (f) $1: 0.5$, (g) $1: 0.7$, (h) $1: 0.8$, (i) $1: 1$, (j) $1: 2$, (k), $1: 3$, (l) $1: 4$. Concentration of the peptide was 2.5 $\times 10^{-4}$ molar. Inset Scatchard plot. 

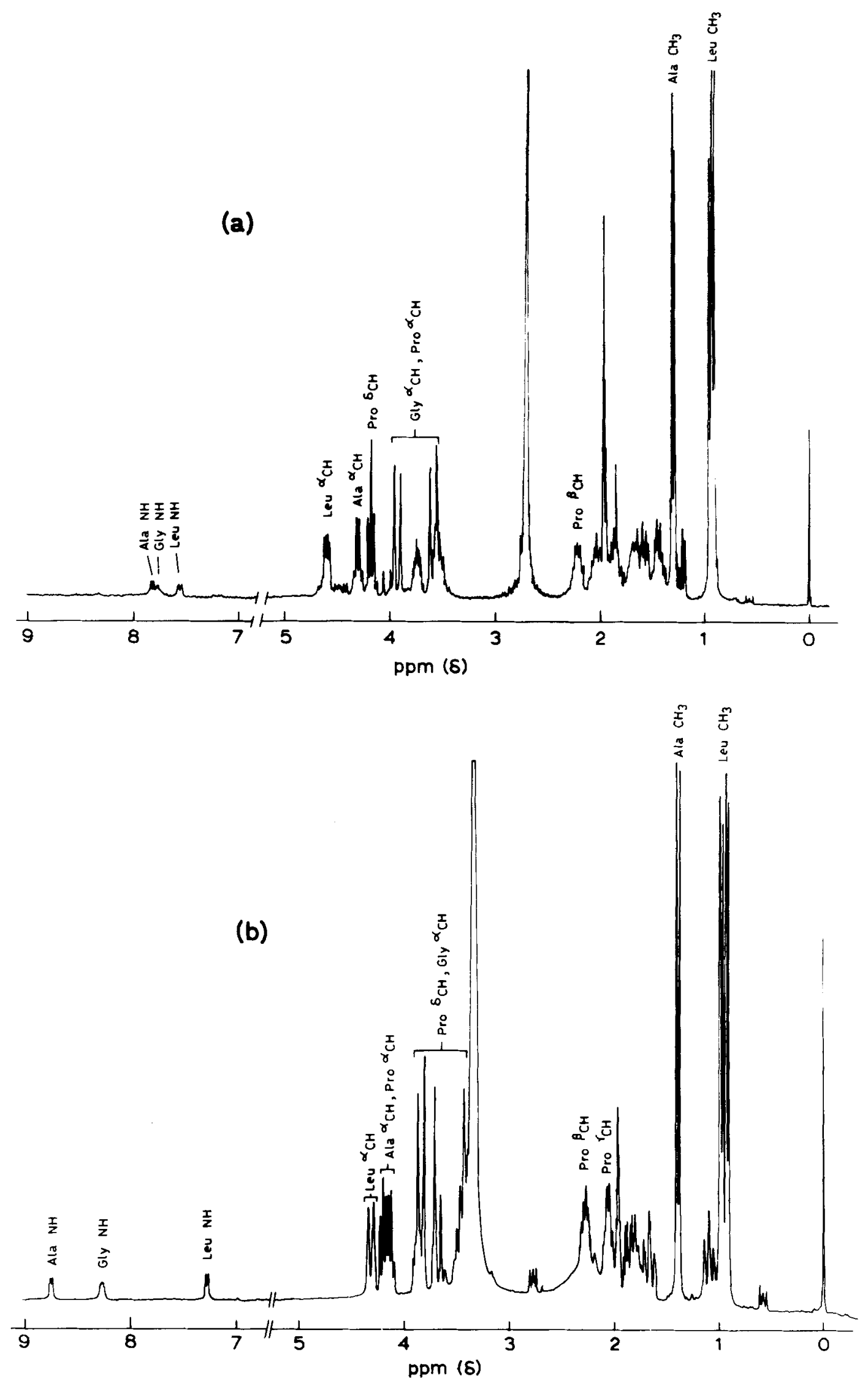

Figure 3. (a) The 270-MHz ${ }^{1} \mathrm{H}-\mathrm{nmr}$ spectrum of free cyclo (Ala-Leu-Pro-Gly) $)_{2}$ (b) The $270-\mathrm{MHz}{ }^{1} \mathrm{H}$-nmr spectrum of cyclic peptide calcium complex (ratio $1: 2$ ) in acetonitrile at laboratory temperature. Concentration of the peptide was 7.0 mmolar. 
washed with ether and in vacuo, yielding $2.4 \mathrm{~g}$ ( 5.3 mmol) peptide; $\mathrm{R}$ fA $0.11, R_{\mathrm{f}} \mathrm{D} 0.35$.

Boc-(Ala-Leu-Pro-Gly) ${ }_{2}$-OBzl (V). A solution of peptide (IV) ( $2.2 \mathrm{~g}, 4.8 \mathrm{mmol}$ ) in DCM, cooled to $-15^{\circ} \mathrm{C}$, was treated with NMM $(0.53 \mathrm{~mL}, 4.8 \mathrm{mmol})$ and iBCC $(0.63 \mathrm{~mL}, 4.7 \mathrm{mmol})$ in DCM (deprotected with TFA snf neutralized with NMM) was added. The reaction mixture was allowed to warm up to room temperature and worked up the next day as described for compound (II). An oily crude material was purified on a silica gel column with a mixture of chloroform-methanol (19.1) as an eluant. Fractions containing pure peptide (V) (tlc) were pooled and evaporated to dryness. The residue was triturated with ether and dried in vacuo. Octapeptide (V) was obtained in a $83 \%$ yield $(3.5 \mathrm{~g}), R_{\mathrm{f}}$ A 0 .

Boc-(Ala-Leu-Pro-Gly) ${ }_{2}$-OH (VI). Protected peptide (V) ( $3.2 \mathrm{~g}, 3.6 \mathrm{mmol})$ in $95 \%$ ethanol was hydrogenated at room temperature in the presence of $10 \%$ palladium on charcoal as a catalyst $(0.4 \mathrm{~g})$. After $5 \mathrm{~h}$ the catalyst was removed by filtration, the solvent evaporated, and the residue triturated with ether. The pure semisolid was collected with $96 \%$ yield.

C(Ala-Leu-Pro-Gly $)_{2}$ (VII). A sample of compound (VI) $(0.8 \mathrm{~g}, 1.0 \mathrm{mmol})$ was treated with TFA. After $0.5 \mathrm{~h}$, no more material could be detected by tlc and TFA was removed in vacuo. The residue was triturated with ether, filtered, and dried. It was subsequently dissolved in a mixture of DMF $(120 \mathrm{~mL})$ and THF $(80 \mathrm{~mL})$, cooled to $-15^{\circ} \mathrm{C}$, treated with iBCC $(0.14 \mathrm{~mL}, 1.0 \mathrm{mmol})$. After $15 \mathrm{~min}$ a precooled mixture of DMF $(360 \mathrm{~mL})$ and THF $(240 \mathrm{~mL})$ containing $0.45 \mathrm{~mL}$ of NMM was added. Next day the solvents were removed in vacuo. The residue was then dissolved in chloroform, washed a few times with $10 \%$ citric acid, water, $0.5 \mathrm{~N} \mathrm{NaHCO}_{3}$, and water, and then dried over $\mathrm{MgSO}_{4}$. Removal of $\mathrm{MgSO}_{4}$ and the solvent left an oily residue that was applied on a silica gel column and eluted with a mixture of ethyl acetate-pyridine-acetic acid-water $(60: 20: 6: 11)$. Fractions containing the pure monocyclic peptide (single spot on the tlc) were pooled and evaporated to dryness. The peptide was desalted on a column of Rexyn I 300 using $50 \%$ ethanol as an eluant. The product was precipitated from a mixture of methanol-ether: $0.52 \mathrm{~g},(76 \%) \mathrm{mp} \mathrm{235-}$ $238^{\circ} \mathrm{C}$, mass spectrum $(\mathrm{M}+\mathrm{H})+678$ (field desorption and fast atom bombardment), correct amino acid analysis.

\section{Methods}

The CD spectra were recorded on a Jasco J-500 spectropolarimeter. The $\mathrm{nmr}$ spectral data were obtained on a Bruker WH-270 nmr and $400-\mathrm{MHz}$ spectrometers at the sophisticated instrument facility, Bangalore. The $\mathrm{CD}$ and $\mathrm{nmr}$ were done in acetonitrile solvent as it is a lipophilic solvent and the peptide forms good metal complexes in this solvent.

\section{RESULTS}

\section{Studies}

The CD spectra of cyclo (Ala-Leu-Pro-Gly $)_{2}$ in different solvents is shown in Figure 1. The spectra in
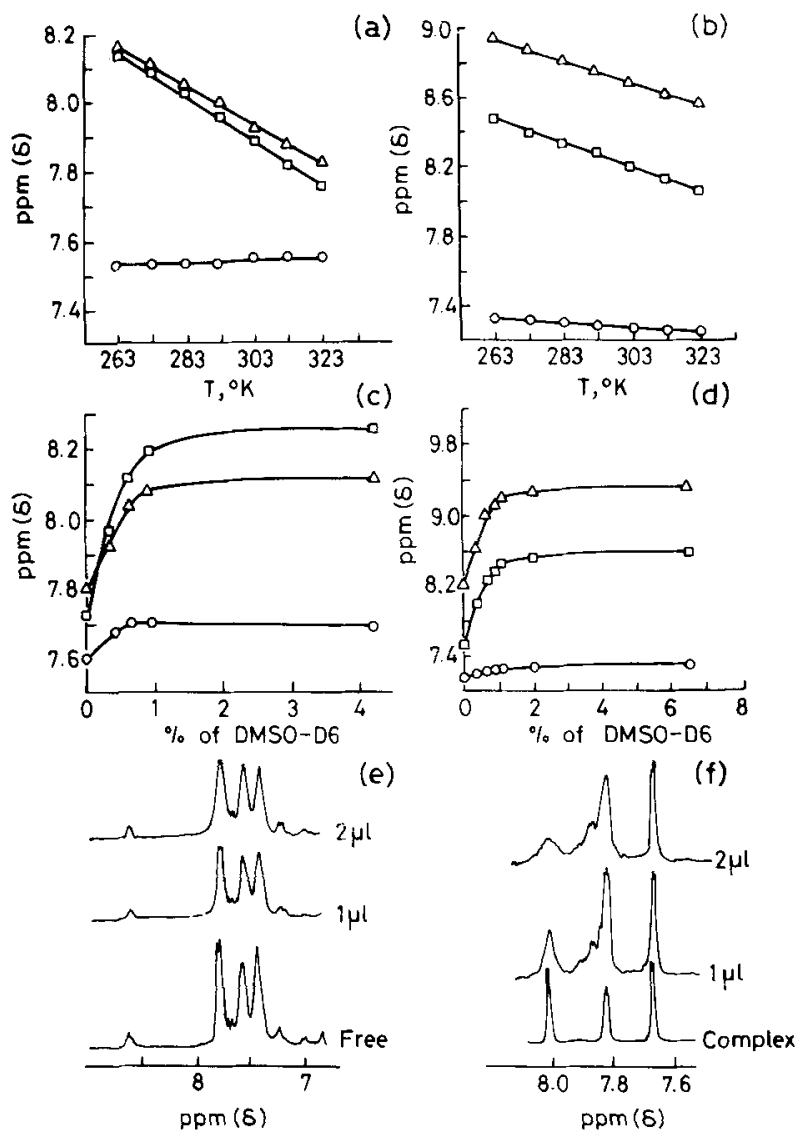

Figure 4. Temperature dependence of $\mathrm{NH}$ chemical shifts of (a) free peptide and (b) cyclic peptide calcium complex (1:2). Solvent dependence of NH chemical shifts of (c) cyclic peptide, free, and (d) cyclic peptide calcium complex. ( $\triangle$ ) Ala, ( $\square)$ Gly, and (O) Leu. (e) and (f) Broadening of $\mathrm{NH}$ resonances by the addition of TEMPO (Tetramethyl piperidinol-1 oxy) to the cyclic peptide in free and complexed form with calcium. 
water, methanol, and trifluoroethanol are quite different from that in the less polar solvents such as acetonitrile, chloroform and hexane. The ellipticity value of the negative $C D$ band around $220 \mathrm{~nm}$, due to the $n-\pi^{*}$ transition from the peptide amide bond decreased in magnitude and shifted toward lower wavelength with increasing polarity of the solvent. Changes were also observed in magnitude and position of the positive $\mathrm{CD}$ band around 200 $\mathrm{nm}$. The data suggests the possibility of the cyclic peptide exhibiting conformations in polar solvents different from that observed in nonpolar solvents.

Addition of perchlorate salts of various monovalent $\mathrm{Na}^{+}, \mathrm{K}^{+}$, and $\left.\mathrm{Li}^{+}\right)$and divalent $\left(\mathrm{Ca}^{2+}, \mathrm{Mg}^{2+}\right.$, and $\mathrm{Ba}^{2+}$ ) cations showed remarkable changes in the CD spectrum of the cyclic peptide complexes. Maximum changes were observed for $\mathrm{Ca}^{2+}$ and $\mathrm{Ba}^{2+}$ complexes. The negative band around $220 \mathrm{~nm}$ com- pletely reverses, exhibiting a large positive ellipticity in the case of divalent cation complex. The changes in the CD curve on complexation is probably due to the involvement of the peptide carbonyl participating in the complexation with the calcium ion. The $\mathrm{CD}$ spectra of the cyclic peptide at various molar concentration ratios of calcium perchlorate salt is shown in Figure 2. Analysis of the titration curves (Figure 2) ${ }^{14}$ indicates that at low salt concentration (below a calcium:peptide ratio of 0.5 ) the calcium complex exist as a sandwich $(2: 1)$ (peptide:calcium) complex and at high salt concentration $(R>0.5)$ both $1: 1$ and $2: 1$ complexes coexist with the $2: 1$ complex more predominant. That more than one form of complex exists in the solution is shown by the nonlinearity of the Scatchard plot (inset of Figure 2) with $\bar{\nu}=\left[\Delta[\theta] / \Delta[\theta]_{\max }\right] \times R^{-1}$ as $X$ axis and $\left(\bar{\nu} / I_{0}\right)=\left[\Delta[\theta] / \Delta[\theta]_{\max }-\Delta[\theta]\right] \times[\text { peptide }]^{-1}$ as

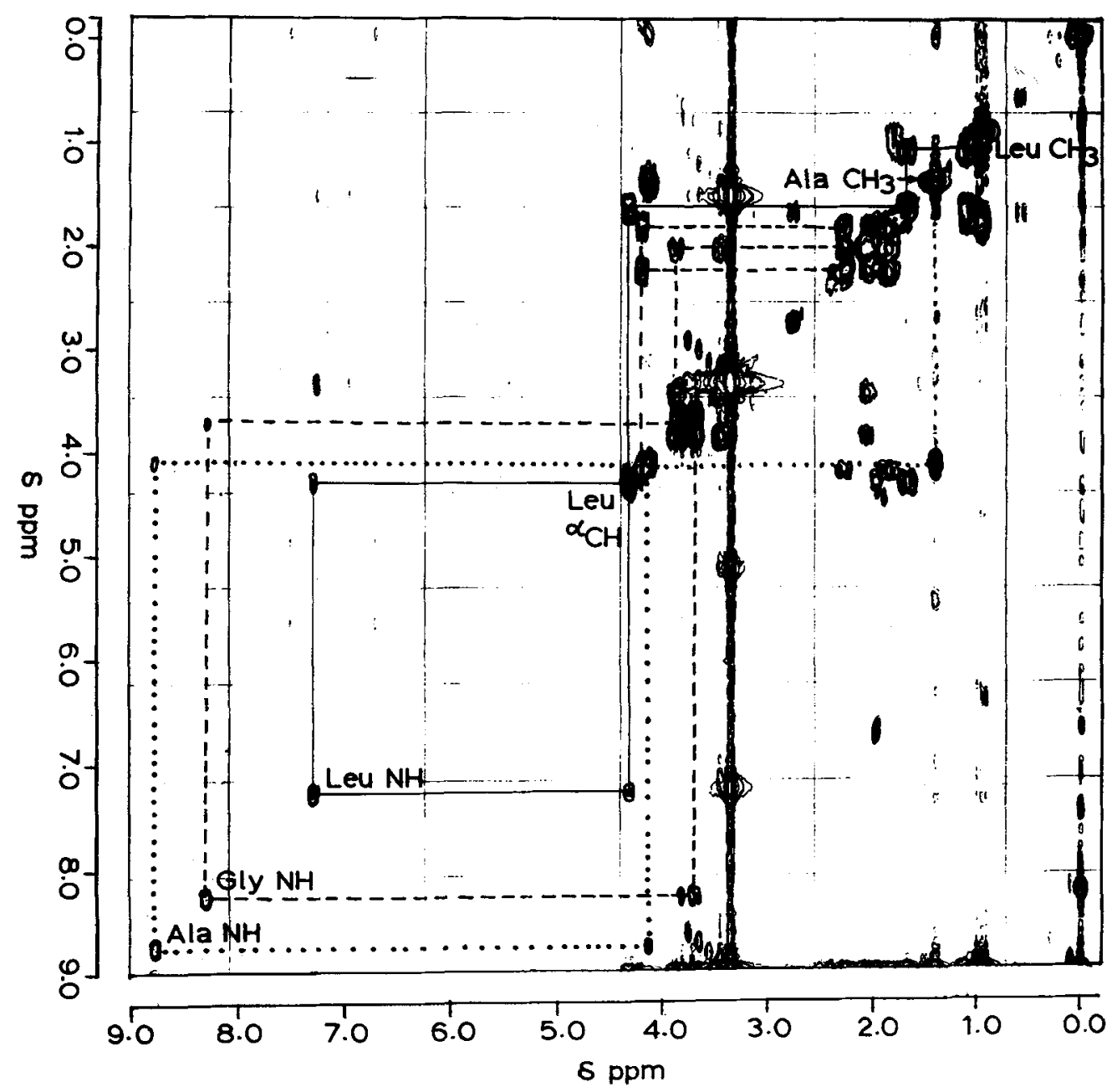

Figure 5. The 270-MHz ${ }^{1} \mathrm{H}-{ }^{1} \mathrm{H}$ COSY spectrum of cyclo (Ala-Leu-Pro-Gly) ${ }_{2}$ calcium complex. Concentration of the peptide was 10 mmolar. 
Table I The 270-MHz ${ }^{1} \mathrm{H}-\mathrm{NMR}$ Data of cyclo(Ala-Leu-Pro-Gly) 2 Free and Complexed with Calcium in Acetonitrile at Laboratory Temperature

\begin{tabular}{|c|c|}
\hline Cyclic Peptide, Free & $\begin{array}{l}\text { Peptide : Calcium } \\
\text { Complex }(1: 1.5)\end{array}$ \\
\hline Ala $\delta$ NH 7.85 & 8.76 \\
\hline$\Delta \delta / \Delta T 5.63 \times 10^{-3}$ & $6.55 \times 10^{-3}$ \\
\hline$J 7.81$ & 5.16 \\
\hline Leu $\delta$ NH 7.58 & 7.29 \\
\hline$\Delta \delta / \Delta T 3.77 \times 10^{-4}$ & $2.12 \times 10^{-3}$ \\
\hline$J 7.45$ & 5.63 \\
\hline Gly $\delta$ NH 7.77 & 8.28 \\
\hline$\Delta \delta / \Delta T 6.63 \times 10^{-3}$ & $7.00 \times 10^{-3}$ \\
\hline - & $9.18^{\mathrm{b}}$ \\
\hline Ala $\delta^{\alpha} \mathrm{CH} 4.32{ }^{\beta} \mathrm{CH} 1.32$ & ${ }^{\alpha} \mathrm{CH} 4.11{ }^{\beta} \mathrm{CH} 1.41$ \\
\hline Leu $\delta{ }^{\alpha} \mathrm{CH} 4.62{ }^{\beta} \mathrm{CH} 1.70$ & ${ }^{\alpha} \mathrm{CH} 4.33^{\beta} \mathrm{CH} 1.80$ \\
\hline${ }^{\alpha} \mathrm{CH} 1.46{ }^{\delta} \mathrm{CH} 0.94$ & ${ }^{\alpha} \mathrm{CH} 1.80{ }^{\circ} \mathrm{CH} 1.8$ \\
\hline Gly $\delta^{\alpha} \mathrm{CH} 3.96,3.61$ & ${ }^{\alpha} \mathrm{CH} 3.81,3.71$ \\
\hline Pro $\delta{ }^{\alpha} \mathrm{CH} 4.18^{\beta} \mathrm{CH} 2.23$ & ${ }^{\alpha} \mathrm{CH} 4.22,{ }^{\beta} \mathrm{CH} 2.31$ \\
\hline${ }^{\alpha} \mathrm{CH} 2.0{ }^{\delta} \mathrm{CH} 3.56$ & ${ }^{\alpha} \mathrm{CH} 2.06{ }^{\delta} \mathrm{CH} 3.87$ \\
\hline 3.90 & 3.40 \\
\hline
\end{tabular}

a $J$ in $\mathrm{Hz} ; \Delta \delta / \Delta T$ in $\mathrm{ppm} /{ }^{\circ} \mathrm{K} ; \delta$ in ppm.

${ }^{\mathrm{b}}$ In the case of Gly, ${ }^{3} \mathrm{~d} \mathrm{NHCH}_{2}$ is Taken (Ref. 15).

$Y$ axis. $\Delta[\theta]$ is the molar ellipticity at a particular ratio of cation:peptide $(R)$ and $\Delta[\theta]_{\max }$ is the ellipticity at saturated concentration of the cations.

\section{NMR Studies}

Free cyclo(Ala-Leu-Pro-Gly $)_{2}$. The one-dimensional $270-\mathrm{MHz}$ proton spectrum of free cyclo (AlaLeu-Pro-Gly $)_{2}$ is shown in Figure 3a. The spectrum indicates the existence of a C-2 symmetry for the molecule as evidenced by the observations of only one set of resonances from the (Ala-Leu-Pro-Gly) fragment. Resonances of smallest intensity, less than $10 \%$ of the major peaks, are also seen, which are due to the minor conformers. Assignments of the various resonances were done by using homonuclear decoupling and from two-dimensional (2D) correlated spectroscopy (COSY) spectrum. The temperature dependence of the chemical shifts, solvent perturbation, and paramagnetic line broadening of the three amide protons (major NH peaks) are given in Figure 4.

The ${ }^{13} \mathrm{C}$ spectra of the cyclo (Ala-Leu-Pro-Gly) ${ }_{2}$ gave a chemical shift value of $28.54 \mathrm{ppm}$ for the ${ }^{\beta} \mathrm{C}$ carbon and $24.4 \mathrm{ppm}$ for the ${ }^{\gamma} \mathrm{C}$ carbon of the proline residue, indicating that the $\mathrm{X}-\mathrm{Pro}$ bond is trans. ${ }^{7}$
cyclo(Ala-Leu-Pro-Gly) $)_{2}$ : Calcium Complex. The $270-\mathrm{MHz} \mathrm{nmr}$ spectra of the cyclic peptide were recorded at various peptide:calcium perchlorate salt concentrations. The titration graph indicated that this spectra stabilized at $R>1.0$. The spectrum of cyclo (Ala-Leu-Pro-Gly) $)_{2}$ at peptide calcium perchlorate ratio of $1: 1.5$ shown in Figure $3 \mathrm{~b}$ clearly indicates significant salt-induced chemical shift and coupling constant changes between the spectrum of free peptide and the complex. The spectra also showed C-2 symmetry as in the case of free cyclic peptide. However, no minor resonances were seen, indicating the absence of any minor conformers for the complex. The assignments were done using the 2D-COSY spectrum (Figure 5). The chemical shifts and coupling constants data are summarized in Table I. The temperature dependence of the chemical shift, solvent perturbation, and the broadening due to addition of nitroxide free radical of the $\mathrm{NH}$ resonances of the peptide:calcium complex are given in Figure $4 \mathrm{~b}, \mathrm{~d}, \mathrm{f}$. The ${ }^{13} \mathrm{C}$ spectra of the cyclic peptide calcium complex gave the values for proline ${ }^{\beta} \mathrm{C}$ shift as $29.42 \mathrm{ppm}$ and ${ }^{\gamma} \mathrm{C}$ shift as $24.28 \mathrm{ppm}$.

\section{DISCUSSION}

The CD spectra of cyclo (Ala-Leu-Pro-Gly) ${ }_{2}$ shows clearly that the conformation of the peptide is highly

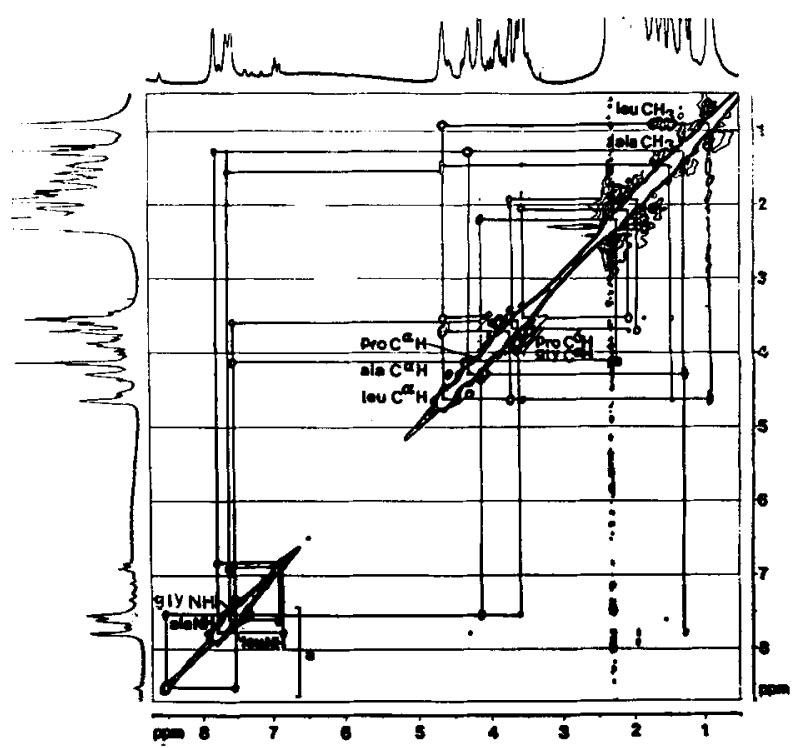

Figure 6. The $400-\mathrm{MHz}$ NOESY spectrum of cyclo (Ala-Leu-Pro-Gly) $)_{2}$ in phase-sensitive mode with a mixing time of $250 \mathrm{~ms}$ (a-exchange cross peaks between major and minor conformers). Concentration of the peptide was 10.0 mmolar. 
solvent dependent. The data taken in acetonitrile showed that the peptide preferentially binds to divalent cations $\mathrm{Ca}^{2+}$ and $\mathrm{Ba}^{2+}$.

\section{Conformation of the Free Peptide}

The ${ }^{1} \mathrm{H}$-nmr spectrum indicated the existence of minor conformation coexisting with the major conformation. The approximate dihedral angles for the various residues were estimated using $J$ vs $\phi$ correlation $^{15}$ (for proline the value is restricted to $-60^{\circ}$ ). CPK (Corey-Pauling-Koltun) and Kendrew models were used to construct possible conformation with estimated $\phi$ values and $\mathrm{nmr}$ data given in Table I. These data indicate that Leu NH is intramolecularly hydrogen bonded whereas Ala $\mathrm{NH}$ and Gly NH are possibly exposed to the solvent. The nuclear Overhauser enhancement spectroscopy (NOESY) spectrum of the cyclic peptide with $250 \mathrm{~ms}$ mixing time is shown in Figure 6. There are inter- and intraresidue NOEs. The interresidue NOEs depend on the intervening torsion angle. ${ }^{16}$ The conformational constraints obtained from $\mathrm{nmr}$ data are given in the Table II. The amide region of the NOESY spectrum showed cross peaks that are of opposite in sign to the other cross peaks, which showed the exchange between major and minor conformers. The probable conformation satisfying the data has the following approximate dihedral angles $(\phi, \psi)$, the angles being obtained from model building. ${ }^{17}$

$\begin{array}{crrr}\text { Ala } & \text { Leu } & \text { Pro } & \text { Gly } \\ \phi-80 & -125 & -60 & 30 \\ \psi+52 & 162 & 143 & -134\end{array}$

The proposed conformation has two possible intramolecular hydrogen bonds, one involving the Leu $\mathrm{NH}$ with $\mathrm{C}=\mathrm{O}$ of $\mathrm{Gly}$, giving rise to a 7 -membered $\gamma$-turn, and the other involving Leu $\mathrm{NH}$ with the $\mathrm{C}=\mathrm{O}$ of Pro, giving rise to a 10 -membered type $\Pi^{\prime}$ $\beta$-turn. Such bifurcated hydrogen bonds contributing to a $\gamma$ - as well as a $\beta$-turn was earlier observed in cyclic hexapeptide (Gly-Pro-Gly) $2 \cdot{ }^{18}$ The proposed conformation is also consistent with nmr data where proline ${ }^{\beta} \mathrm{C}$ and ${ }^{\gamma} \mathrm{C}$ carbon chemical shifts correspond to a trans Leu-Pro bond. ${ }^{7}$ In such a model, four carbonyls point outward on one side of the molecule with a Leu side chain on the other side. Such a con-

Table II Conformational Constraints Derived from NMR Data for cyclo(Ala-Leu-Pro-Gly) 2

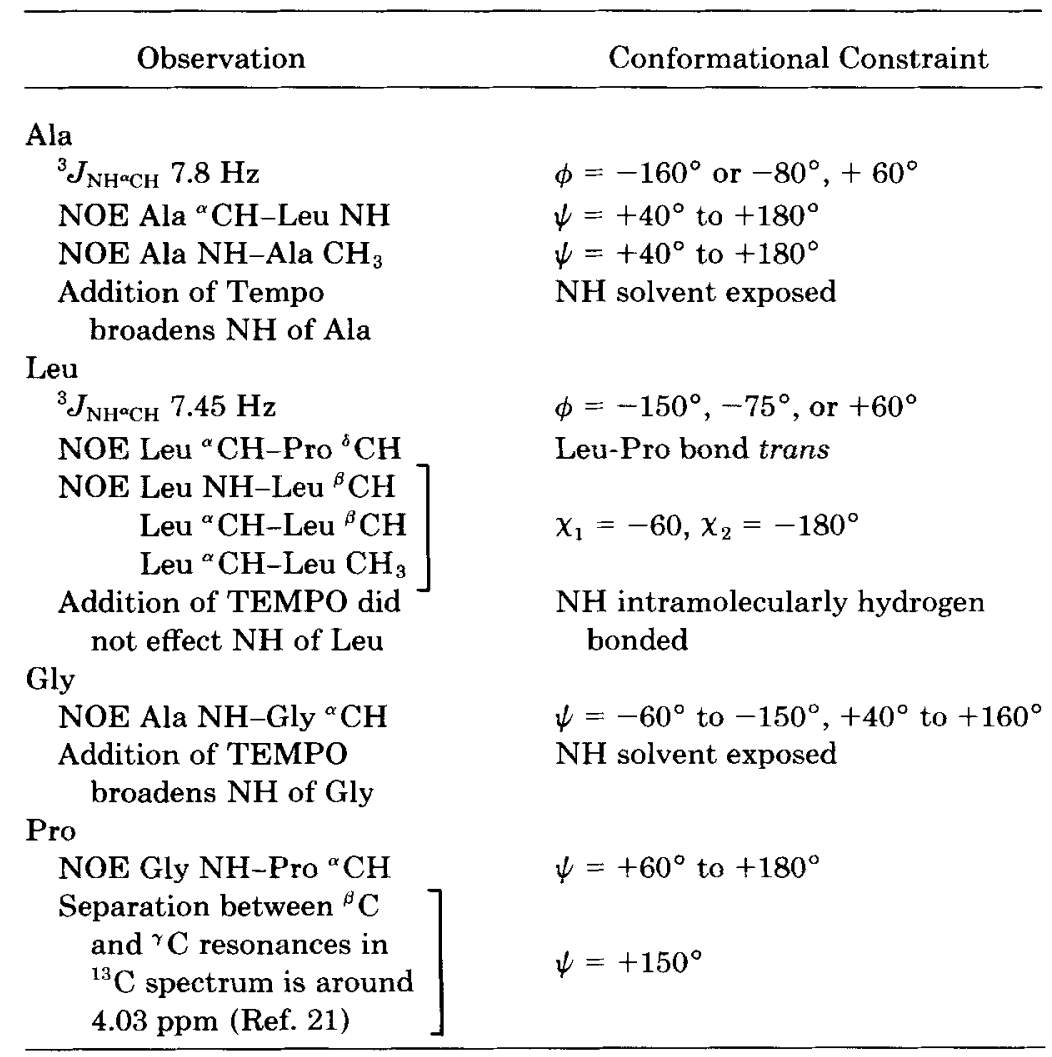


formation is also ideally suited for the binding of a suitable cation from one side of the molecule. The proposed model was cyclized using $\mathrm{nmr}$ data by computer program using standard peptide geometry. ${ }^{19}$ This conformation is in agreement with that built using Kendrew models for the cyclic peptide.

\section{Conformation of the cyclo (Ala-Leu-Pro-Gly) 2 Calcium Complex}

The ${ }^{1} \mathrm{H}$-nmr data for the calcium complex of the cyclic peptide (Table I) clearly showed salt-induced chemical shifts and coupling constant changes indicating the binding of the calcium ion to the peptide and possible conformational changes for the molecule. The approximate dihedral angles were estimated using the $J$ vs $\phi$ correlation. ${ }^{15}$ The data (Table I) also showed that the Leu NH is intramolecularly hydrogen bonded, and the Gly and Ala NHs are exposed to the solvent even in the complex. However, there are indications (temperature coefficient of chemical shift of amide resonances) that the intramolecular hydrogen bond is stronger in the free peptide than the peptide in complex form. It can also be seen that there are no minor conformers present. NOESY data (figure not shown) indicates NOE between Ala NH-Leu NH, which is usual in turns ${ }^{16}$ and a sequence-specific NOE between Ala $\mathrm{NH}-\mathrm{Gly}{ }^{\alpha} \mathrm{CH}$. There is also NOE between Leu ${ }^{\alpha} \mathrm{CH}-$ Pro ${ }^{\delta} \mathrm{CH}$, which is indicative of a trans Leu-Pro bond. The conformation satisfying the estimated dihedral angles and the data are given in Table I and Figure 7, has the following approximate dihedral angles ${ }^{17}$ :

$\begin{array}{crrr}\text { Ala } & \text { Leu } & \text { Pro } & \text { Gly } \\ \phi-70 & -90 & -60 & 30 \\ \psi \quad 30 & 160 & 145 & -120\end{array}$

The conformation for the complex is quite similar to that of the free peptide. The $\beta$-turn involving the Pro $\mathrm{C}=\mathrm{O}$ and Leu $\mathrm{NH}$ is strengthened with a weakening of the 7-membered hydrogen bond in the $\gamma$-turn. The ${ }^{13} \mathrm{C}$-nmr data and the Pro ${ }^{\beta} \mathrm{C}$ and ${ }^{\gamma} \mathrm{C}$ carbon is also consistent with the model showing the Leu-Pro bond as trans. In addition, on complexation two of the carbonyl resonances shifted dramatically from the original position $(1.2 \mathrm{ppm})$. Carbonyl resonances could not be assigned unambiguously. However, the two carbonyls that showed large shifts in the calcium complex are likely to be Leu $\mathrm{C}=\mathrm{O}$ and Gly $\mathrm{C}=\mathrm{O}$.

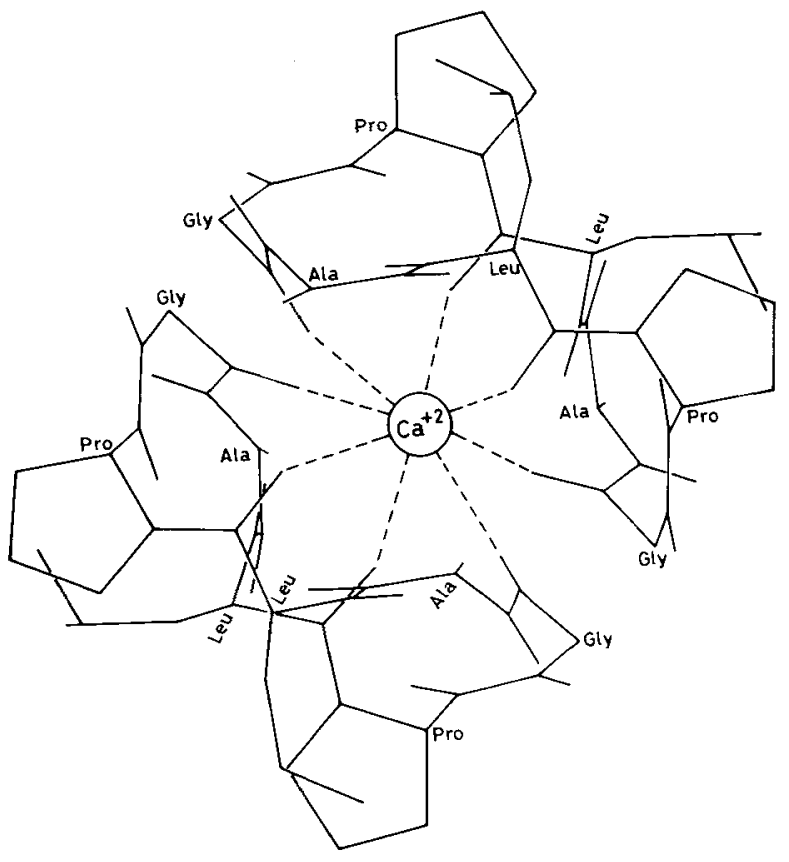

Figure 7. Computer-drawn proposed model for cyclo (Ala-Leu-Pro-Gly) ${ }_{2}$ calcium "sandwich" complex.

In summary, our $\mathrm{CD}$ and $\mathrm{nmr}$ showed that the cyclo (Ala-Leu-Pro-Gly) $)_{2}$ specifically binds to divalent cations such as calcium and barium. Detailed $\mathrm{nmr}$ studies indicated that the overall conformation of free cyclic peptide having two $\gamma$ - and two $\beta$-turns and its calcium complex having two $\beta$-turns are not very different. The conformation is of special interest in that we have four carbonyls pointing out on one face of the molecule (two of the carbonyls being involved in intramolecular hydrogen bond) and with a cavity ideal for cation binding and the bulky side chain of Leu and Pro on the other side. The model indicated that the peptide can readily form a equimolar complex with cations and possibly a $2: 1$ (peptide : ion) complex. One of the interesting and unusual observation in the cyclic peptide conformations is the absence of the proline at the turn (in our model the residues participating in the $\gamma$-turn are (Gly-Ala-Leu).

Further work on this cyclic peptide and its calcium complex in solid state using single crystal $x$ ray diffraction is in progress.

This work was supported, in part, by U.S. Public Health Service Grants AM07300 and AM10794 (ERB) and a UGC centre for Advanced Study Grant for Advanced Study grant to Molecular Biophysics Unit, Indian Institute of Science, Bangalore, India. 


\section{REFERENCES}

1. Ovchinnikov, Yu. A., Ivanov, V. T. \& Shkrob, A. M. (1974) Membrane Active Complexions, Elsevier Scientific, Amsterdam.

2. Easwaran, K. R. K. (1987) in Ion Transport Through Membranes, Yagi, K. \& Pullman, B., Eds., Academic Press, Orlando, FL, pp. 17-39.

3. Giebisch, G., Tosteson, D. C. \& Ussing, H. H. (1980) in Membrane Transport in Biology, Vol. 3, SpringerVerlag, Berlin.

4. Pressman, B. C. (1976) Ann. Rev. Biochem. 45, 501530.

5. Ovchinnikov, Yu. A. \& Ivanov, V. T. (1975) Tetrahedran 31, 2177-2209, and references therein.

6. Deber, C. M., Madison, V. \& Blout, E. R. (1977) J. Am. Chem. Soc. 99, 4788-4798.

7. Deber, C. M., Madison, V. \& Blout, E. R. (1976) Accts. Chem. Res. 9, 106-113.

8. Rose, G. D., Gierasch, L. M. \& Smith, J. (1985) Adv. Protein Chem. 37, 1-109.

9. Tolle, J. C., Staples, M. A. \& Blout, E. R. (1982) J. Am. Chem. Soc. 104, 6883-6884.

10. Staples, M. A., Tolle, J. C. \& Blout, E. R. (1983) in Conformation in Biology, Srinivasan, R. \& Sarma R. H., Eds., Adenine Press, New York, pp. 147-154.

11. Campbell, B., Easwaran, K. R. K., Zanotti, G. C., Sta- ples, M. A., Fossel, E. T. \& Blout, E. R. (1986) Biopolymers 25, S47-S60.

12. Bednarek, M. A., Campbell, B. E., Easwaran, K. R. K. \& Blout, E. R. (1987) Biopolymers 26, S11S23.

13. Zanotti, G. C., Campbell, B. E., Easwaran, K. R. K. \& Blout, E. R. (1988) Int. J. Peptide Protein Res. 32, 527-535.

14. Reuben, J. (1973) J. Am. Chem. Soc. 95, 3534-3540.

15. Bystrov, V. F., Ivanov, V. T., Portnova, S. L., Balashova, T. A. \& Ovchinnikov, Yu. A. (1973) Tetrahedron 29, 873-877.

16. Wuthirch, K. (1986) in NMR of Proteins and Nucleic Acids, Wiley-Interscience New York, pp. 117-127.

17. IUPAC-IUB Commission on Biochemical Nomenclature (1970) Biochem. J. 121, 577-585.

18. Deber, C. M. \& Blout, E. R. (1974) Isr. J. Chem. 12, 15-29.

19. Momany, F. A., McGuire, R. F., Burgess, A. W. \& Scheraga, H. A. (1975) J. Phys. Chem. 79, 2361-2381.

20. Pease, L. G., Deber, C. M., Madison, V., Niu, C. H. \& Blout, E. R. (1981) Biochemistry 20, 4730-4738.

21. Siemion, I. Z., Wieland, T. \& Pook, K.-H. (1975) Angew. Chem. Int. Ed. 14, 702-703.

Received April 26, 1991

Accepted January 16, 1992 